\title{
Book Review: Moser, K., \& Zelaya, K. (Eds.). (2020). The Metaphor of the Monster: Interdisciplinary Approaches to Understanding the Monstrous Other in Literature. Bloomsbury Publishing USA
}

\author{
Heather Alberro (Corresponding author) \\ Nottingham Trent University \\ Email: Heather.alberro@ntu.ac.uk
}

Received: $12 / 02 / 2021$

Accepted: 10/05/2021

Published: 01/07/2021

Volume: 2 Issue: 4

How to cite this paper: Alberro, H. (2021). Book Review: Moser, K. and Sukla, A. Ch. (Eds). (2020). Book Review: Moser, K., \& Zelaya, K. (Eds.). (2020). The Metaphor of the Monster: Interdisciplinary Approaches to Understanding the Monstrous Other in Literature. Bloomsbury Publishing USA. Journal of Critical Studies in Language and Literature, 2(4), 27-29

DOI: https://doi.org/10.46809/jcsll.v2i4.75

Copyright (C) 2020 by author(s) and Global Talent Academy Ltd. This work is licensed under the Creative Commons Attribution International License (CC BY 4.0).

http://creativecommons.org/licenses/by/4.0/

(c) (i)

"There is, though I do not know how there is or why there is, a sense of infinite peace and protection in the glittering hosts of heaven. There, it must be, I think, that whatever is more than animal within us must find its solace and its hope" (Wells, 1978, p. 156).

This engrossing interdisciplinary collection, edited by French studies Professor Keith Moser and Central American literary scholar Karina Zelaya of Mississippi State University, explores numerous iterations- historical, literary, ecological, sexual- of the monstrous 'other'. As such, the collection would be of interest and relevance to scholars from a host of disciplines: from international relations and security studies to environmental ethics and postcolonial studies. The work is divided into four parts, each featuring essays that correspond to a particular sub-discipline within monster studies: Part I (Ecological perspectives), Part II (Transgressive, Monstrous gender and Corporality), Part III (Teaching monstrosity in the (Post-)Modern World), and Part IV (Monstrosity in World Literature). This structure is particularly useful in helping the reader discern the unique contributions offered by each field to the analysis of monster metaphors.

Historically and presently the metaphor of the ' monster' has been powerfully associated with women (especially female criminals who doubly err by transgressing both gender and legal norms) (Daly \& Chesney-Lind 1988), migrants, bodies that don't conform to rigid male/female sexual binaries (Ghadessi in Moser \& Zelaya 113), nonhuman animals (Moser in Moser \& Zelaya 2020), unfamiliar landscapes wherein wanderers not attuned to the ebbs and flows of the terrain fall prey to their own ignorance (Adams in Moser \& Zelaya 101), and Ancient Greek assignations of the 'monstrous' to races inhabiting spaces beyond the polis or 'city-state' (Watanabe in Moris \& Zelaya 206). Within Western culture, the label of monstrosity has often been assigned to any being or entity deviating from the European, white, heterosexual middle class male 'master identity' (Plumwood 2002). Yet the metaphor of the monster, as this collection adeptly demonstrates throughout its myriad interventions, is anything but ubiquitous or stable. Monsters variedly complicate, transgress and also reify boundariesbetween the human and nonhuman, the real and the possible (Cohen 2007). And crucially, as the dual etymology of the word 'monster' suggests- denoting both 'to show' and, more ominously, to 'portend'- definitions of 'monstrosity' are porous, ambiguous and subject to change. 
The figure of the monster harbours many paradoxes. Touba Ghadessi's chapter explores the long contested nature of the nebulous hermaphroditic body, variedly seen as a monstrous deviation from sexual norms and in other contexts as a perfect harmony of masculine and feminine traits, and the complexities that arise when a powerful sovereign like Francois I is depicted as occupying such a contested position (in Moser \& Zelaya 113). This trope of duality at the heart of the monster metaphor is similarly explored in Jonathan Krell's insightful chapter on the Melusine myth and the meandering depictions of this curious mythological hybrid figure- both male and female, human and monstrous 'other', evil and good, and- as the chapter's apt title denotes- both monster and victim (50). It is the monster's 'in-betweenness' and radical alterity, which violates boundaries by both excess and lack (Carandina in Moser \& Zelaya 133), that likely accounts for its enduring transgressive potential, as well as numerous attempts to repress it or ostracise it.

Derridean deconstruction $(1994 ; 2010)$ surfaces as a key theoretical thread (Krell 61; Moser 72) in this edited collection, namely for its powerful legacy in dismantling binary logics and critiquing the reduction of the 'other' - i.e. nonhuman animals long depicted as only seen rather than seeing (The Animal That Therefore I am) by a sovereign humanity- to the status of inferior object that can be fully known, manipulated and rendered amenable to exploitation. Moser's chapter, drawing on Derrida's posthumous work on non-human otherness, highlights an important problematic within his work that further echoes throughout this edited collection: the profound ethico-political ramifications stemming from the varied application of the 'monster metaphor' in its banishment of all manner of beings considered less or other-than human, indeed to any exceeding the bounds of a hegemonic normality, to the 'no man's land' of moral inconsequentiality (70). This dynamic recalls the 'Men Against Fire' (2016) episode in season 3 of the dystopian thriller series Black Mirror, wherein soldiers in the future are implanted with special lenses that literally portray the 'enemy' as monstrous mutants so as to render their annihilation ethically unproblematic. The 'other'- like the future itself- appears monstrous through its unrecognizability (Derrida 2010, 266).

A point which might have been underscored even more forcefully throughout this collection is that of the monster that lies within those of us who oppress, exploit and otherwise relegate 'others' to a status of inferiority. The monstrous resides in hegemonic power structures (Mir in Moser \& Zelaya 215) such as capitalism, patriarchy, racism, neo-colonialism, anthropocentrism, and heteronormativity- reproduced through millions of micro-interactions- which portray a litany of others as there for the taking. Neill Barrett's engaging chapter traces the parallels between misogynistic incel violence, Mary Shelley's Frankenstein, and John Milton's Paradise Lost wherein the vague spectre of death is most frequently characterised as the 'monster' (155). Likewise, one might further locate modern monstrosity in extractive capital's appropriation of the world in service of its sole objective of maximising profits, resulting in the annihilation of our co-terrestrials via the sixth mass extinction (Ceballos et al 2020). Unsurprisingly, Frankenstein's monster serves as another cross-cutting reference throughout many of the collection's essays, and as a fitting metaphor for contemporary 'technological crimes' against the nonhuman world amidst the Capitalocene (Moore 2017). Though, as Bruno Latour (2011) points out, Dr. Frankenstein's- and modern capitalism's- true crime isn't the act of technological hubris per se, but that of abandoning the monsters they've created and effectively disavowing ethical responsibility for their existence and its ramifications. We thus tend to blame technological monsters like factory trawlers rather than ourselves as their creators- or more specifically the boundless extractive logic of capital- for the ecological devastation resulting from their use (Latour 20).

Through its multidisciplinary exploration of the myriad forms that monsters have taken across time and space, this edited collection presents an engaging and thought-provoking glimpse into the varied applications and effects of the notion of monstrosity. To varying degrees the essays within urge greater care, closer scrutiny and self-reflection in relation to the monsters within us and of our own making. Indeed, the final essay by Scott Truesdale on the tensions between inclinations towards indulging in hedonistic pursuits which objectify others and a desire for their just and ethical treatment exhibited by Albert Camus's Don Juan gestures towards the elements of heroism as well as monstrosity in all of us (236). Crucially, monsters aren't mere literary figures that haunt the cultural imagination; monstrosity resides in austerity and anti-immigration policies, in extractive mindsets, in the longstanding denial of the agency and inherent worth of our terrestrial kin, and in the absence of empathy and compassion towards others. Following Latour (2011) and Haraway (2016), we ought to 'stay with the trouble' that we've created on terra and face our ethical responsibilities to all others- monstrous and otherwise.

\section{References}

Ceballos, G., Ehrlich, P. R., \& Raven, P. H. (2020). Vertebrates on the brink as indicators of biological annihilation and the sixth mass extinction. Proceedings of the National Academy of Sciences, 117(24), 13596-13602.

Cohen, J. J. (2007). "Monster culture (seven theses)." Gothic horror: A guide for students and readers.198-217.

Daly, K., \& Chesney-Lind, M. (1988). Feminism and criminology. Justice quarterly, 5(4), 497-538.

Derrida, J., \& Wills, D. (2002). The animal that therefore I am (more to follow). Critical inquiry, 28(2), 369-418.

Derrida, J. (2010). The Beast and the Sovereign, Volume I . University of Chicago Press.

Haraway, D. J. (2016). Staying with the trouble: Making kin in the Chthulucene. Duke University Press.

Bruno, L. (2011). "Love your monsters." Breakthrough Journal, 2(11), 21-28.

Moore, J. W. (2017). The Capitalocene, Part I: on the nature and origins of our ecological crisis. The Journal of peasant studies, 44(3), 594-630. 
Brooker, C. Huq, K., Jones, R., Armstrong, J. Shur, M. \& Bridges, W. (2016). 'Men Against Fire'. Black Mirror, Season 3, Episode 5.

Plumwood, V. (2002). Feminism and the Mastery of Nature. Routledge.

Wells, H. G. (1978). The Complete Science Fiction Treasury of HG Wells. Random House Value Publishing. 